\title{
PEMBERDAYAAN IBU-IBU DAN REMAJA TANI DALAM PENGELOLAAN LAHAN SEMPIT UNTUK BUDIDAYA SAYURAN HIJAU DENGAN METODE SERI-PLANTING
}

\author{
Arinfadira Ramadhanti ${ }^{1^{*}}$, M. Fahrizal ${ }^{2}$, Retno Ayu Mutmainah ${ }^{3}$, I Ketut Ngawit ${ }^{4}$ \\ ${ }^{1}$ Pendidikan Bahasa Inggris, Fakultas Keguruan dan Pendidikan, Universitas Mataram \\ 2Manajemen, Fakultas Ekonomi dan Bisnis, Universitas Mataram \\ 3Pendidikan Guru Sekolah Dasar, Fakultas Keguruan dan Pendidikan, Universitas Mataram \\ ${ }^{4}$ Fakultas Pertanian, Universitas Mataram \\ ${ }^{*}$ Co-Author : maehwagi@gmail.com
}

\begin{abstract}
ABSTRAK. Telah dilakukan pelatihan pembuatan spesimen awetan organisme kepada guru-guru di provinsi NTB. Kegiatan ini bertujuan untuk meningkatkan keterampilan guru dalam membuat media pembelajaran untuk menunjang pelajaran keanekaragaman hayati disekolah. Kegiatan ini dilakukan selama 4 hari dari tanggal 30 Oktober-2 November 2017 yang diikuti oleh 34 guru yang ada di NTB. Melalui kegiatan ini, para guru diperkenalkan tentang keanekaragaman hayati yang ada di NTB khususnya dan Indonesia pada umumnya. Selain itu para guru juga dilatih melakukan sampling dan pengawetan flora dan fauna yang ada disekitar lingkungan tempat tinggal. Tehnik fotografi dan manajemen spesimen awetan diberikan untuk menambah softskill para guru sehingga spesimen yang dikoleksi dapat disimpan dalam jangka waktu yang lama. Para peserta pelatihan memberikan respon yang positif terhadap kegiatan ini. Hal tersebut dapat diketahui melalui jumlah peserta yang melebihi target, antusiaisme dalam mengikuti setiap kegiaatan dan permintaan untuk diundang dalam pelatihan-pelatihan berikutnya yang diadakan Universitas Mataram. Desa Barejulat kecamatan Jonggat merupakan salah satu desa agraris yang dikelompokkan sebagai desa yang berkembang. Lahan pertanian yang subur dikarenakan pasokan air yang cukup melimpah membuat sebagian masyarakatnya memiliki sumber mata pencaharian pada bidang bercocok tanam, baik kegiatan pertanian maupun perkebunan. Hal ini ditunjukkan oleh digunakannya lahan seluas 299,746 Ha sebagai lahan persawahan dan 8,500 Ha sebagai lahan perkebunan dari total luas desa barejulat yaitu $455,000 \mathrm{Ha}$. Akan tetapi masih banyak terdapat lahan sempit yang belum di optimalkan terutama dalam budidaya sayuran hijau. Sebagian besar Masyarakat desa barejulat berprofesi sebagai petani padi dan tanaman holtikultura. Jumlah petani yang menanam sayuran hijau masih sangat dikit dengan jenis tanaman kacang panjang dan kangkung. Untuk dapat mengoptimalkan potensi yang dimiliki oleh desa barejulat dan sekaligus sebagai upaya untuk meningkat perekonomian di wilayah tersebut, diperlukan tindakan pembinaan atau pemberdayan yang berkelanjutan dan sinambung mengenai cara pengelolaan lahan melalui model usahatani tersebut adalah sistem budidaya tanam siklus seri dan budidaya lorong (Allay cropping) dengan menggunakan tanaman tahunan (cabai) sebagai tanaman pokok dan tanaman sayur-sayuran semusim(bayam dan sawi) sebagai tanaman lorong. Dengan ada nya penyuluhan dan demonstrasi plot sebagai lahan percontohan terhadap metode ini, masyarakat Desa Barejulat dapat mengoptimalkan pengelolaan lahan sempit dengan penanaman sayuran hijau yang dapat menjadi mata pencaharian baru.
\end{abstract}

\section{Kata Kunci: Pemberdayaan, Pengelolaan, Lahan Sempit, Seri-Planting, Budidaya Sayuran Hijau}

ABSTRACT. There has been a specimen of the preservation of organism for the teachers in NTB province. The village of Barejulat district of Jonggat is one of the agrarian villages classified as a thriving village. Fertile agricultural land due to the abundant water supply is able to make some of the community has a source of livelihood in the field of planting, both agricultural and plantation activities. This is demonstrated by the use of a land area of $299.746 \mathrm{Ha}$ as paddy fields and 8.500 $\mathrm{Ha}$ as plantation land of the total area of Barejulat village of $455.000 \mathrm{Ha}$. But there are still many narrow land that has not been optimized especially in the cultivation of green vegetables. Most of the village community Barejulat as rice farmers and horticultural crops. The number of farmers who grow green vegetables is still very little with the type of long beans and kale. To be able to optimize the 
potential owned by the village Barerange and as well as an effort to increase the economy in the region, it is necessary to conduct sustainable coaching or Land through the farming model is the cultivation system of the cycle series and the cultivation of hallways (Allay cropping) by using annual plants (chili) as a staple plant and seasonal vegetable plants (spinach and mustard) as a niche plant. With the existence of counseling and demonstration plot as a pilot land against this method, the community of Barejulat village can optimize the management of narrow land with the planting of green vegetables that can become a new livelihood.

Keyword: empowerment, management, narrow land, series-planting, cultivation of green vegetables.

\section{PENDAHULUAN}

Desa Barejulat secara administratif merupakan desa yang terletak di Kecamatan Jonggat, Kabupaten Lombok Tengah dengan luas wilayah $455 \mathrm{Ha}$. Mayoritas penduduk warga Desa Barejulat bermata pencaharian sebagai petani, sebagian besar lain nya berprofesi sebagai peternak dan PNS. Lahan seluas 299,746 Ha sebagai lahan persawahan dan 8,500 Ha sebagai lahan perkebunan menunjukan bahwa desa ini merupakan desa agraris. Akan tetapi budidaya sayuran hijau seperti bayam dan sawi masih belum dioptimalkan dan ditambah pula dengan banyak nya lahan sempit yang belum digarap, menjadi sebuah permasalahan di desa ini. Kurang nya penyuluhan pertanian dan penting nya untuk menanam sayuran hijau adalah salah satu faktor kenapa masyarakat desa barejulat belum aktif dalam mengoptimalkan lahan sempit yang mereka miliki untuk penanaman sayuran hijau.

Untuk dapat mengoptimalkan potensi yang dimiliki oleh desa barejulat dan sekaligus sebagai upaya untuk mengurangi penduduk miskin di wilayah tersebut, diperlukan tindakan pembinaan yang berkelanjutan dan sinambung mengenai cara pengelolaan lahan, bagi penduduk sekitar yang berprofesi sebagai petani. diperlukan tindakan pembinaan atau pemberdayan yang berkelanjutan dan sinambung mengenai cara pengelolaan lahan melalui model usahatani tersebut adalah sistem budidaya tanam siklus seri dan budidaya lorong (Allay cropping) dengan menggunakan tanaman tahunan (cabai) sebagai tanaman pokok dan tanaman sayur-sayuran semusim(bayam dan sawi) sebagai tanaman lorong. Dengan ada nya penyuluhan dan demonstrasi plot sebagai lahan percontohan terhadap metode ini, masyarakat Desa Barejulat dapat mengoptimalkan pengelolaan lahan sempit dengan penanaman sayuran hijau yang dapat menjadi mata pencaharian baru.

\section{ANALISIS PERMASALAHAN}

Sebagain besar warga Desa Barejulat memiliki lahan pekarangan yang sempit dan tidak termanfaatkan. Adapun hal ini terjadi karena masyarakat memiliki pengetahuan yang minim dalam pengelolaan tanaman. Namun, optimalisasi pemanfaatan lahan ini tidak didukung dengan penyuluhan pertanian dari pihak-pihak terkait. Sehingga masyarakat sekitar tidak dapat mengoptimalkan fungsi sebagai sumber kehidupan rumah tangga.

\section{SOLUSI YANG DITAWARKAN}

Metode pendekatan yang diterapkan untuk penyelesaian permasalahan dalam pengelolaan model produksi yang direncanakan adalah Program Tindak Partisipatif (Participatori Action Program), yaitu mahasiswa KKN melibatkan ibu-ibu dan remaja yang ada di desa Barejulat untuk mengikuti program yang diadakan. Pendekatan yang dilakukan adalah dari bawah dan dari atas (Bottom-up and top down approach) dengan memperhatikan pengetahuan, keterampilan dan kearifan para ibu-ibu dan remaja yang ada di desa Barejulat (indigeneus knowledge).

Bentuk kegiatan secara keseluruhan dalam program ini adalah 1) Persiapan program, 2) Sosialisasi tentang metode seriplanting 3) Pelatihan metode seri-plantinng 4) Pengaplikasian hasil pelatihan di lahan yang telah di siapkan 5) Monitoring dan evaluasi. 


\section{HASIL DAN PEMBAHASAN}

Program pemberdayaan masyarakat Desa Barejulat dilakukan secara terstruktur dan melibatkan masyarakat secara langsung. Kegiatan pembedayaan masyarakat ini dimulai dengan persiapan progran yang meliputi survei lokasi. Hasil survei menujukan bahwa kendala yang dihadapi masyarakat Desa Barejulat antara lain 1) Banyak nya lahan sempit yang belum digunakan 2) belum diterapkan metode pertanian yang dapat dapat meningkatkan perekonomian 3) masih kurang nya petani sayuran.

Penyuluhan dan Pelatihan Metode Seri-Planting dilaksanakan di rumah kader dusun Loang Sawak yang dihadiri oleh masyarakat dusun Loang Sawak sendiri dan perwakilan dari dusun-dusun lain. Penyuluhan pertama tentang gambaran umum seri-planting lalu dilanjutkan dengan penyuluhan cara penanaman sayuran hijau seperti bayam dan sawi. Setelah penyuluhan berakhir, ada sesi diskusi dan tanya jawab antara dosen pembimbing lapangan sebagai pemateri dengan masyarakat terhadap permasalahan pertanian.

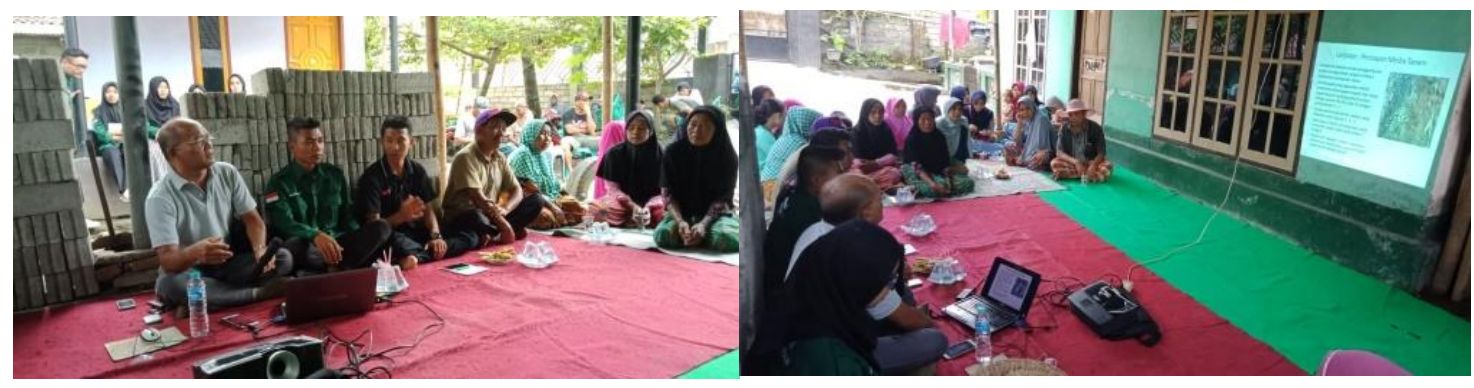

Gambar 1. Penyuluhan metode seri-planting

Setelah penyuluhan berakhir, maka selanjut nya adalah pelatihan yang dilakukan dialahan warga setempat. Mahasiswa KKN, DPL dan masyakat bersama-sama mengolah lahan hingga proses penanaman.

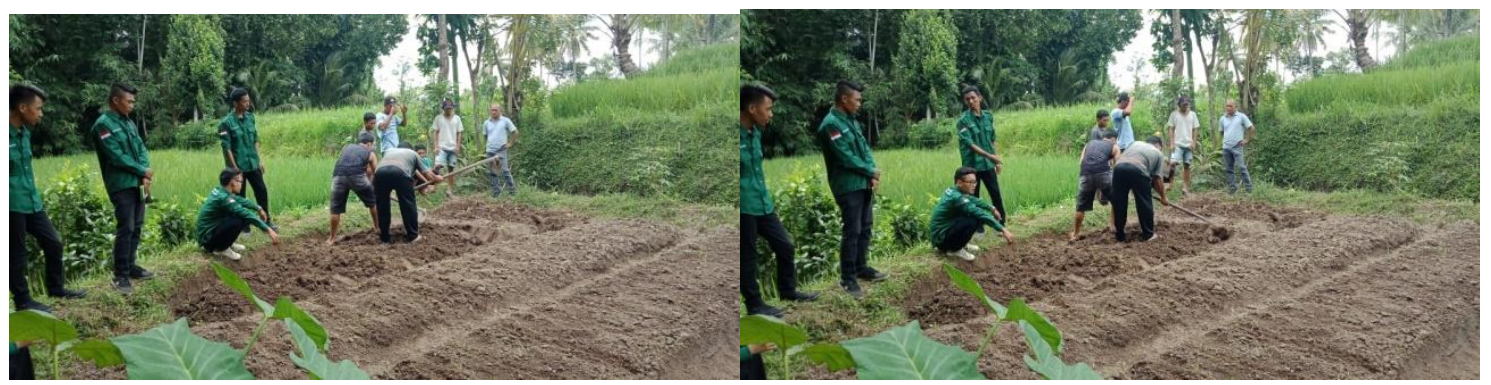

Gambar 2. Pelatihan penanaman sayuran dengan metode seri-planting

Monitoring dan Evaluasi Monitoring dan evaluasi kontinu dilakukan bersamaan dengan pendampingan program. Hasil monitoring berkelanjutan Evaluasi program secara umum menunjukan bahwa masyarakat dan kelompok tani Desa Barejulat berkomitmen memanfaatkan dan mengolah lahan sempit untuk budidaya sayuran hijau untuk meningkat kan perekonomian 


\section{KESIMPULAN}

Kesimpulan dari program penyuluhan dan pelatihan budi daya sayuran hijau pada lahan sempit kepada masyarakat adalah masyarakat Desa Barejulat dapat mengolah lahan sempit yang belum digunakan untuk penanaman sayuran hijau yang berkelanjutan. Sehingga masyarakat terutama ibu-ibu tani dapat memiliki penghasilan tambahan dan warga Desa Barejulat tidak perlu lagi membeli sayuran hijau di luar desa.

\section{REFERENSI}

Erfandi D., A. Dariah. and H. Suwardjo. (1989). Pengaruh A lley Cropping terhadap Erosi dan Produktivitas Tanah Haplorthox Citayam. Proceeding on Pertemuan Teknis Penelitian Tanah, Bidang Konservasi Tanah dan Air, Bogor, August 22-24: Pusat Penelitian Tanah dan Agroklimat (CSAR), Badan Penelitian dan Pengembangan Pertanian (AARD).

Haryati U. 2002. Keunggulan dan Kelemahan Sistem Alley Cropping Serta Peluang dan Kendala Adopsinya di Lahan Kering DAS Bagian Hulu. Makalah Pengantar Falsafah Sains. Program Pasca Sarjana (S3) Institut Pertanian Bogor (IPB). Bogor.

Luthful Hakim, 2002. Strategi Perencanaan dan Pengelolaan Lahan Kering Secara Berkelanjutan Di Kalimantan. Makalah Falsafah Sains, Program Pascasajana. Institut Pertanian Bogor. Bogor.

Ngawit, I Ketut, 2001. Usaha Agribisnis dengan Sistem Budidaya Lorong (Allay Croping) antara Tanaman Pisang Cavendis dengan Beberapa Jenis Tanaman Buah Semusim di Wilayah Pengembangan Lahan Kering Kecamatan Bayan Kabupaten Lombok Barat NTB. Makalah Seminar Program Pengembangan Budaya Kewirausahaan di PT, DP3M, Direktorat Jenderal Pendidikan Tinggi, Jakarta.

Ngawit, I Ketut, 2002. Optimalisasi Penerapan Teknologi Budidaya Lorong (Allay Croping) antara Tanaman Buah-Buahan Tahunan dengan Beberapa Jenis Tanaman Sayur-sayuran semusim di Wilayah Pengembangan Lahan Kering Kecamatan Bayan Kabupaten Lombok Barat NTB. Makalah Seminar Program Pengembangan Budaya Kewirausahaan di PT, DP3M, Direktorat Jenderal Pendidikan Tinggi, Jakarta.

Ngawit, I Ketut, L. Irasakti dan H. Abdurrachman, 2000. Efisiensi Penggunaan Irigasi Air Tanah dalam Upaya Peningkatan Produktivitas Lahan Kering dan Pendapatan Petani Jagung di Kecamatan Bayan, Lombok Barat, NTB. Makalah Seminar Penerapan Ipteks, Dirjen Dikti, Jakarta, Maret, 15-17.

Syekhfani. 1993. Pengaruh sistim pola tanam terhadap kandungan bahan organik dalam mempertahankan kesuburan tanah. Makalah disajkan dalam Seminar Nasional Budidaya Pertanian Olah Tanah Konservasi di Universitas Lampung. Bandar Lampung.

Utomo. M. 1990. Budidaya Pertanian Tanpa Olah Tanah Teknologi Untuk Pertanian Berkelanjutan. Pertemuan Teknis Direktorat Bina Produksi. Departemen Pertanian. Jakarta. 